\title{
Strategies and Difficulties of Learning English Idioms Among University Students
}

\author{
Dr. Mohammad Abd Alhafeez Ali Ta'amneh \\ Associate Professor of Teaching English as a Foreign Language (TEFL), Taibah University
}

\begin{abstract}
This study investigated the strategies and difficulties of learning English idioms among university students. The sample consisted of one hundred and twenty-nine students enrolled in the second semester of the academic year 2020/2021. The researcher prepared a questionnaire to identify the strategies employed by students to facilitate learning idioms and to explore the difficulties that faced them during their learning. The results showed that the participants had difficulty to learn idioms. They also revealed that the most common used strategies were predicting the meaning of the idioms, translating them to the first language, guessing the meaning of idiomatic expressions from the context, depending on verbal and visual information, and looking up unfamiliar idioms in the dictionary. The researcher gave some pedagogical implications and recommendations about learning idioms for further studies.
\end{abstract}

Keywords: Idiomatic expressions, figurative meaning, learning strategies, learning difficulties, innovative learning strategies

DOI: $10.7176 / \mathrm{JEP} / 12-23-10$

Publication date:August $31^{\text {st }} 2021$

\section{Introduction}

English language is a universal language that is used to communicate among scholars and educated people who know the meaning and pronunciation of several English words. Teachers try to find different effective methods to teach it better to their students. Consequently, they have to make a stimulating learning environment to increase positive learners' attitudes toward EFL learning. Learning idiomatic expressions is often viewed as an important technique for foreign language learners to achieve successful communication. The English language is rich of idioms (Brenner, 2011; Zyzik, 2011). De Caro (2009) states that without using idioms, English will lose much of its diversity. An idiom is " a term used in grammar and lexicology to refer to a sequence of words which are semantically or syntactically restricted so that they function as a single unit. From a semantic viewpoint, the meaning of the individual words cannot be summed to produce the meaning of the idiomatic expression as a whole. From a syntactic viewpoint, the words do not often permit the usual variability they display in other contexts" (Crystal, 1991: 170). Therefore, there are some difficulties and problems in understanding and comprehending them. According to Asri and Rochmawati (2017), understanding idiomatic expressions is considered to be problematic for foreign language learners.

Lennon (1998) describes idioms as the colorful side of languages. They are used to enhance the language by using the existing vocabulary items, combining them in new sentences and making new meanings and functions. Baker (1992) described idioms as "frozen patterns of language which allow little or no variation in form, and in the case of idioms, often carry meaning which cannot be deduced from their individual components" (p. 63). Similarly, Richards and Schmidt (1990) identified an idiom as "an expression which functions as a single unit and whose meaning cannot be worked out from separate parts" (p. 246). Alexander (1987) defined them as "multi-word units which have to be learned as a whole, along with associated sociolinguistic, cultural and pragmatics rules of use" (p. 178). According to Cooper (1999), idioms play a vital role in foreign language learning by providing learners with particular vocabulary items that help them in using and understanding the language effectively.

Meanwhile, learning idioms could be one of the most problematic parts of foreign language learning because of their arbitrary nature. Charteris-black (2002) states that figurative idioms are challenging for foreign language learners since the meanings of several idioms could not be comprehended through understanding their grammatical and lexical elements. As a result, this could make some difficulties and problems in the systematic instructions of idioms.

\section{Statement of the Problem}

Learning English requires a lot of practice and communication. Learners who have the ability to use English in their learning and daily life situations can receive the information better. Ta'amneh 2014 states that "vocabulary has been recognized as crucial to language use in which insufficient vocabulary knowledge of the learners led to difficulties in foreign language learning" ( p. 155). EFL teachers teach students traditionally to memorize new vocabulary items, do exercises, read and answer questions without asking them to use these items in real-life situations and real or virtual communication. Learning English is considered to be a difficult task for students 
because of little contact with the target language and native speakers of English in daily life events. Learning English idioms is possibly the hardest task to be achieved. According to Glucksberg (1993), understanding the meaning of the idioms may be known from the meaning of one of their subcomponents but usually, the meaning is totally different.

Learning idiomatic expressions needs innovative learning strategies."Students had a tendency to learn vocabulary through using ready translation found in some books or depending on explanations given by their teachers, and they did not like to spend a lot of time when learning new vocabulary" (Ta'amneh, 2015 ,p. 83 ). Idiomatic expressions are phrases that have different meanings than the literal translation of their words. Therefore, the learners need to be more educated when learning these expressions to understand and comprehend them better. Learning these figurative expressions is considered to be problematic for learners. The meanings of idioms can not always be derived from the literal meanings of their words (Strakšiene, 2009). "Many idiomatic phrases appear to be decomposable or analyzable, with the meanings of their parts contributing independently to their overall figurative meaning" (Asri and Rochmawati, 2017, p. 47).

\section{Significance of the Study}

The major aim of carrying out this research is to know the strategies and difficulties of learning English idioms among university students at Taibah University. The significance of this study stems from the fact that there are few studies investigated this issue. This study may help students to use effective strategies and solve some problems when learning idiomatic expressions. It may also provide teachers and decision-makers with improvements needed to develop the process of learning idioms. In the same vein, this study may provide researchers with some suggestions and implications to create an effective and valuable learning environment.

\section{Purpose of the Study}

The current study aims at identifying the strategies of learning English idioms among university students . It also aims to discover the difficulties and challenges that affect students' learning.

\section{Questions of the Study}

This study attempts to answer the following questions:

1- What are the difficulties that EFL students face when learning English idioms?

2- What are the strategies that EFL students use to facilitate learning idiomatic expressions?

\section{Literature Review}

Teaching idioms to foreign language learners is difficult because it needs particular knowledge about the words' context (O`Malley and Chamot, 1990, p. 210-211). According to Beloussova (2015), learning idiomatic expressions is not easy and needs special attention. Even native speakers of English face difficulties in using and understanding idioms (Mäntylä 2004). Consequently, learners should learn them depending on their idiomatic knowledge which is essential to understand and use idioms correctly and appropriately (Burke, 1998). Traditional idiomatic learning strategies focus on rote learning and memorization (Chen and Lai, 2013). In contrast, learners and instructors need more modern effective and efficient strategies when learning and teaching idioms (SelvaRaj and Hua, 2019).

Irujo (1984) conducted a study to identify whether second language students used their knowledge of the first language to use and understand idioms in their second language. The study discussed some strategies used by learners to produce English idioms. The researcher used identical, similar, and different idioms in English and Spanish to know students' strategies to produce unfamiliar idioms. The results showed that identical idioms were easier to understand and produce. The students used both interlingual and intralingual strategies to use idioms they did not understand. They also revealed that the students used their Spanish knowledge to understand English idioms. In addition, the results showed that the participants faced difficulties and problems in comprehending and producing different idioms.

Abu-Afeefa (1987) examined whether Jordanian students used their knowledge of the first language to understand English idioms. One hundred and twenty-eight Jordanian university students participated in this study and took a test to assess their comprehension and production of thirty-six English idioms. The findings revealed that the participants were able to make generalizations concerning identical idioms. They also indicated that the production of similar idioms reflected interference as a result of using translation.

Using a sample of English major students at the Department of Language and Literature in Bahrain, AlHassan (2007) carried out a study to explore the feasibility of Arab learners in guessing the meanings of unfamiliar English idioms and recognize the effectiveness of students' strategies in translating these idioms. The findings showed that the participants were unable to make the correct translation of some unfamiliar English idioms. In contrast, they provided correct or partially correct translation in the rest of the items. They also revealed that the participants used different strategies to comprehend the meaning of idioms such as idiom 
constituents, sentences, metaphor, context, keywords and guessing.

Similarly, Rohani, Tavakoli, and Ketabi (2012) examined the effect of context on the students' strategies used to learn idiomatic expressions. They wanted to know the main processes involved in understanding idioms by seventy students in the traditional written context and an animated cartoon context. The results showed that think-aloud was the most common strategy that the language learners utilized to comprehend unfamiliar idioms. The results of the think-aloud process showed many strategies the students referred to when comprehending the meaning of new idioms such as drawings on background knowledge, drawing on context, translation, visualization, wild guessing, and paraphrasing.

Saleh and Zakaria (2013) explored difficulties faced by learners when learning idioms and strategies applied to understand them. The sample consisted of forty Libyan students. The results revealed that the lack of cultural background and less exposure to English idioms were the main difficulties for learners. Furthermore, the findings asserted that guessing the meaning of idioms from the context was the most used strategy learners utilized to comprehend idiomatic expressions.

In their study, Al-khawaldeh, Jaradat, Al-momani, and Bani-Khair (2016) investigated students' perception about learning idioms. The sample consisted of one hundred and fifty students at Hashemite University. The results revealed that the participants did not know the significance of dealing with idioms. They also showed that the difficulties learners faced when learning idioms were related to less exposure to English idioms. Besides, the results demonstrated that learners commonly used the context to guess the meaning of English idioms.

Alhaysony (2017) examined the strategies Saudi learners utilized to understand English idioms and explored their difficulties in learning and understanding these idioms. Eighty-five students majoring in English language at Aljouf University participated in this study. The findings revealed that the learners had difficulty to comprehend idioms. They also showed that the most common used strategies were guessing and predicting, and identifying the meaning of idioms. In addition, the findings showed that the participants faced some difficulties when learning English idioms.

My and Loi (2020) explored learners' knowledge of common English idioms in a Vietnamese context. Seventy-six teenage students participated in this study. The results showed that the participants had very limited idiomatic knowledge which considered as a problem for learning English idioms. The researchers suggested an instructional direction for improving students' knowledge of idioms.

In the same vein, Zarei (2020) compared the effectiveness of four ways of teaching EFL learners' comprehension and production of English idioms(visualization, storytelling, game, and lexical awareness techniques). The results indicated that the differences were not significant concerning idioms comprehension but they were effective on idioms production. They also revealed that storytelling was a successful and uncomplicated method to use for learners and instructors.

Orfan (2021) investigated the students' attitudes towards the importance of learning idioms, difficulties faced by learners when learning idiomatic expressions, and strategies used to learn and understand them. Three hundred and thirty-seven students majoring in English language and literature participated in this study. The results revealed that the participants had a positive attitude towards learning idioms. Their problems and difficulties came from the lack of cultural knowledge, the lack of analogues for English idioms in their first language, and the lack of context. The results showed that the participants used several strategies to comprehend idioms.

Finally, Yunus and Hmaidan (2021) conducted a study to explore lecturers' strategies in teaching and translating idiomatic expressions. The sample consisted of Eight English lecturers at four Jordanian universities. The results showed that the lecturers utilized different strategies in their teaching to improve learners' comprehension like authentic materials, teaching within context, using the first language to comprehend the foreign language expressions, pictures, exercises, dialogues and role play. They think that these strategies were effective and useful in teaching idiomatic expressions.

The previous studies provide important information about the process of learning idioms through discussing new approaches and strategies. They also deal with difficulties faced by students when learning idiomatic expressions. The present study investigates the strategies and difficulties of learning English idioms among university students. This research sheds the light on the students' perspectives about the actual attempts to learn idiomatic expressions and offers some clarifications and suggestions to help learners get more advantages and then perform better when learning such expressions.

\section{Methods and Procedures}

7.1 Participants of the study

The participants of the study consisted of 129 students from different departments at Taibah University $\backslash \mathrm{Badr}$ Branch in the Kingdom of Saudi Arabia during the second semester of the academic year 2020/2021. They were selected randomly to participate in this study. 


\subsection{Instrument of the Study}

The researcher designed a five-point Likert-type questionnaire to identify the strategies employed by EFL students in learning idiomatic expressions. It was also used to explore the difficulties faced by students during their learning. It consisted of two parts: the first one consisted of ten items regarding students' difficulties of learning English idioms while the second contained sixteen items concerning idiom learning strategies. The students were asked to choose at which level they agreed with each statement.

7.3 Validity and Reliability of the Instrument

Seven experts were asked to read the questionnaire and give their suggestions. The researcher asked fifteen students to answer the questionnaire twice with a two-week interval between them. The reliability coefficient was calculated using Cronbach Alpha. The calculated value was .83 which is acceptable to do this research.

\subsection{Data Collection}

This research was conducted at Taibah University $\backslash$ Badr Branch during the second semester of the academic year 2020/2021. The researcher obtained the permission of the students to conduct this research. A questionnaire was used to explore the participants' perspectives about the strategies used by students in learning idioms and difficulties faced by them when learning idiomatic expressions. The researcher explained the objectives of the study to the participants to make sure that they gave true responses. 129 students responded to the questionnaire.

\subsection{Data Analysis}

The current study is mainly quantitative research. The mean and standard deviation of each statement in the questionnaire were analyzed using Statistical Package for Social Studies (SPSS).

\section{Results and Discussion}

The results of this study will be presented in two parts. The first one shows the difficulties that learners face during the process of learning idioms, and the second part shows the strategies they utilize to help them in such learning.

\subsection{Difficulty of learning idioms}

The purpose of this research is to explore the strategies of learning English idioms among university students and to discover the difficulties that affect students' learning. To answer the first question "What are the difficulties that EFL students face when learning English idioms?", the frequencies, percentages, means and standard deviations of the students' responses were calculated and analyzed using SPSS program. The results are presented in Table 1.

Table 1. Difficulty of learning idioms

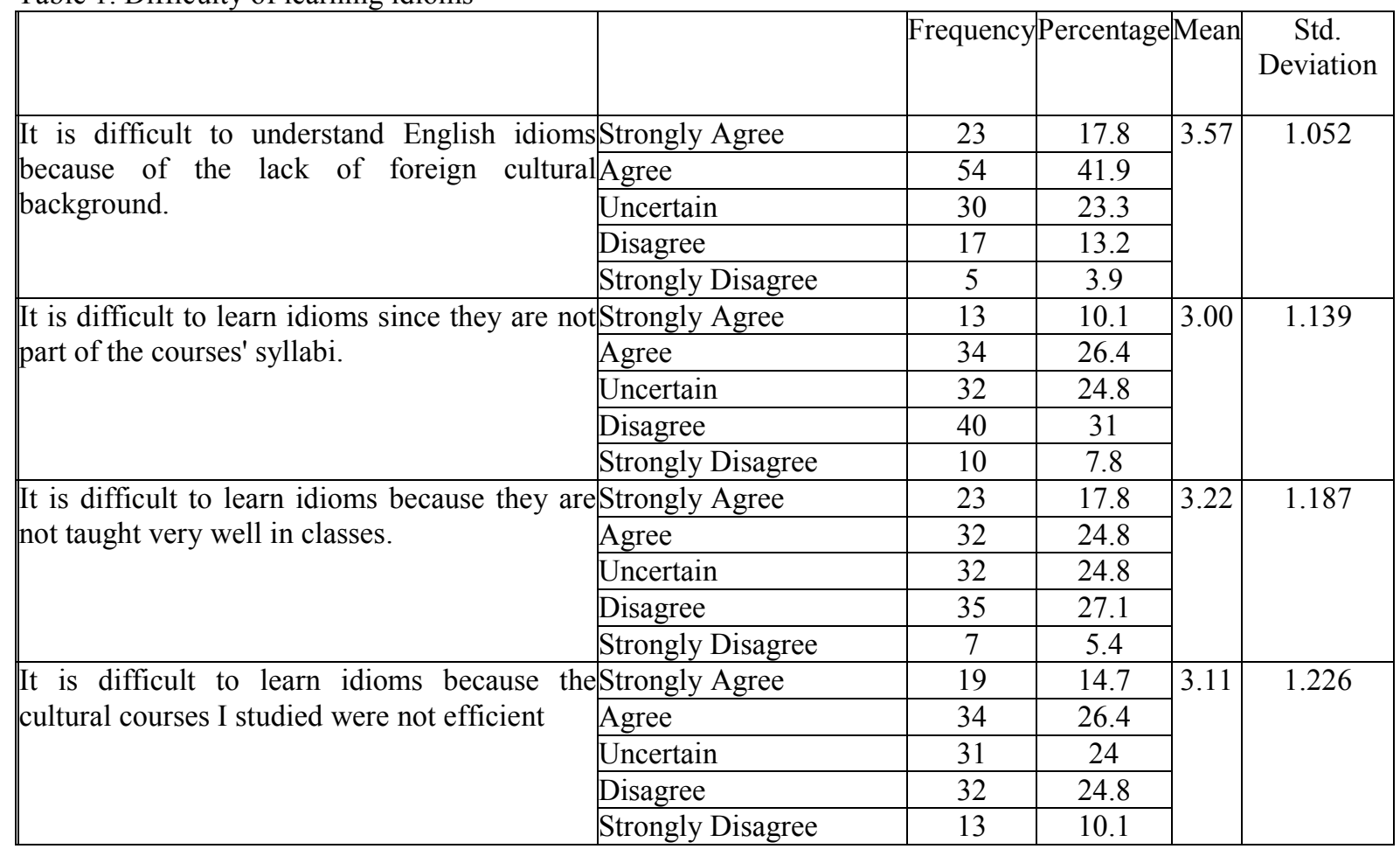




\begin{tabular}{|c|c|c|c|c|c|}
\hline & & Frequenc & yPercentage & elMean & $\begin{array}{c}\text { Std. } \\
\text { Deviation }\end{array}$ \\
\hline $\begin{array}{l}\text { It is difficult to use idioms in oral } \\
\text { communication }\end{array}$ & \begin{tabular}{|l|} 
Strongly Agree \\
Agree \\
Uncertain \\
Disagree \\
Strongly Disagree \\
\end{tabular} & \begin{tabular}{|c|}
29 \\
35 \\
33 \\
24 \\
8 \\
\end{tabular} & \begin{tabular}{|l|}
22.5 \\
27.1 \\
25.6 \\
18.6 \\
6.2 \\
\end{tabular} & 3.41 & 1.203 \\
\hline $\begin{array}{l}\text { It is difficult to expand my knowledge of } \\
\text { idioms in daily life situations. }\end{array}$ & \begin{tabular}{|l|} 
Strongly Agree \\
Agree \\
Uncertain \\
Disagree \\
Strongly Disagree \\
\end{tabular} & \begin{tabular}{|l|}
23 \\
39 \\
32 \\
24 \\
11
\end{tabular} & \begin{tabular}{|c|}
17.8 \\
30.2 \\
24.8 \\
18.6 \\
8.5 \\
\end{tabular} & 3.30 & 1.209 \\
\hline $\begin{array}{l}\text { It is difficult to present idioms in a manner that } \\
\text { mirrors real-life language use. }\end{array}$ & \begin{tabular}{|l|} 
Strongly Agree \\
Agree \\
Uncertain \\
Disagree \\
Strongly Disagree \\
\end{tabular} & \begin{tabular}{|c|}
24 \\
44 \\
41 \\
15 \\
5
\end{tabular} & \begin{tabular}{|c|}
18.6 \\
34.1 \\
31.8 \\
11.6 \\
3.9 \\
\end{tabular} & 3.52 & 1.047 \\
\hline $\begin{array}{l}\text { It is difficult to identify cultural differences } \\
\text { and similarities of idioms. }\end{array}$ & \begin{tabular}{|l|} 
Strongly Agree \\
Agree \\
Uncertain \\
Disagree \\
Strongly Disagree \\
\end{tabular} & \begin{tabular}{c|}
21 \\
42 \\
33 \\
29 \\
4
\end{tabular} & \begin{tabular}{c|}
16.3 \\
32.6 \\
25.6 \\
22.5 \\
3.1
\end{tabular} & 3.36 & 1.096 \\
\hline $\begin{array}{l}\text { It is difficult to understand English figurative } \\
\text { expressions. }\end{array}$ & \begin{tabular}{|l|} 
Strongly Agree \\
Agree \\
Uncertain \\
Disagree \\
Strongly Disagree
\end{tabular} & \begin{tabular}{c|}
24 \\
45 \\
28 \\
26 \\
6
\end{tabular} & \begin{tabular}{c|}
18.6 \\
34.9 \\
21.7 \\
20.2 \\
4.7
\end{tabular} & 3.43 & 1.144 \\
\hline $\begin{array}{l}\text { It is difficult to practice idioms in different } \\
\text { communicative contexts. }\end{array}$ & \begin{tabular}{|l|} 
Strongly Agree \\
Agree \\
Uncertain \\
Disagree \\
Strongly Disagree \\
\end{tabular} & \begin{tabular}{|c|}
23 \\
40 \\
38 \\
23 \\
5
\end{tabular} & \begin{tabular}{|c|}
17.8 \\
31 \\
29.5 \\
17.8 \\
3.9 \\
\end{tabular} & 3.41 & 1.094 \\
\hline
\end{tabular}

As shown in the above table, the majority of the students found the process of learning idioms difficult. They faced problems in comprehending and understanding idiomatic expressions because of poor idiomatic competence. This indicates that the students do not have enough knowledge about English idioms or they need to learn more and more foreign cultures.

The results revealed that the participants encountered several difficulties when learning English idioms. It can be noticed that the difficulties were as follows: lacking foreign cultural background (59.9\%), presenting idioms in a manner that mirrors real-life language use (44.7\%), understanding English figurative expressions $(53.5 \%)$, using idioms in oral communication (49.6\%), practicing idioms in different communicative contexts (48.8\%), identifying cultural differences and similarities of idioms (49.1\%), expanding learner's knowledge of idioms in daily life situations (38\%), and learning idioms very well in classes $(42.6 \%)$. This indicates that the students do not have enough knowledge about English idioms or they need to learn more about foreign cultures. Such difficulties could also be ascribed to other reasons such as the unfamiliar vocabulary and new idioms, cultural differences, lack of training to deal with idiomatic expressions. EFL learners sometimes find it difficult to identify idioms' structures and understand their meanings. They have to be aware that developing their idiomatic awareness may help them develop their communicative language skills.

\subsection{Strategies for Learning Idioms}

To answer the second question "What are the strategies that EFL students use to facilitate learning idiomatic expressions?", the frequencies, percentages, means and standard deviations of the students' responses were calculated and analyzed as shown in Table 2. 
Table 2. Strategies for learning idioms

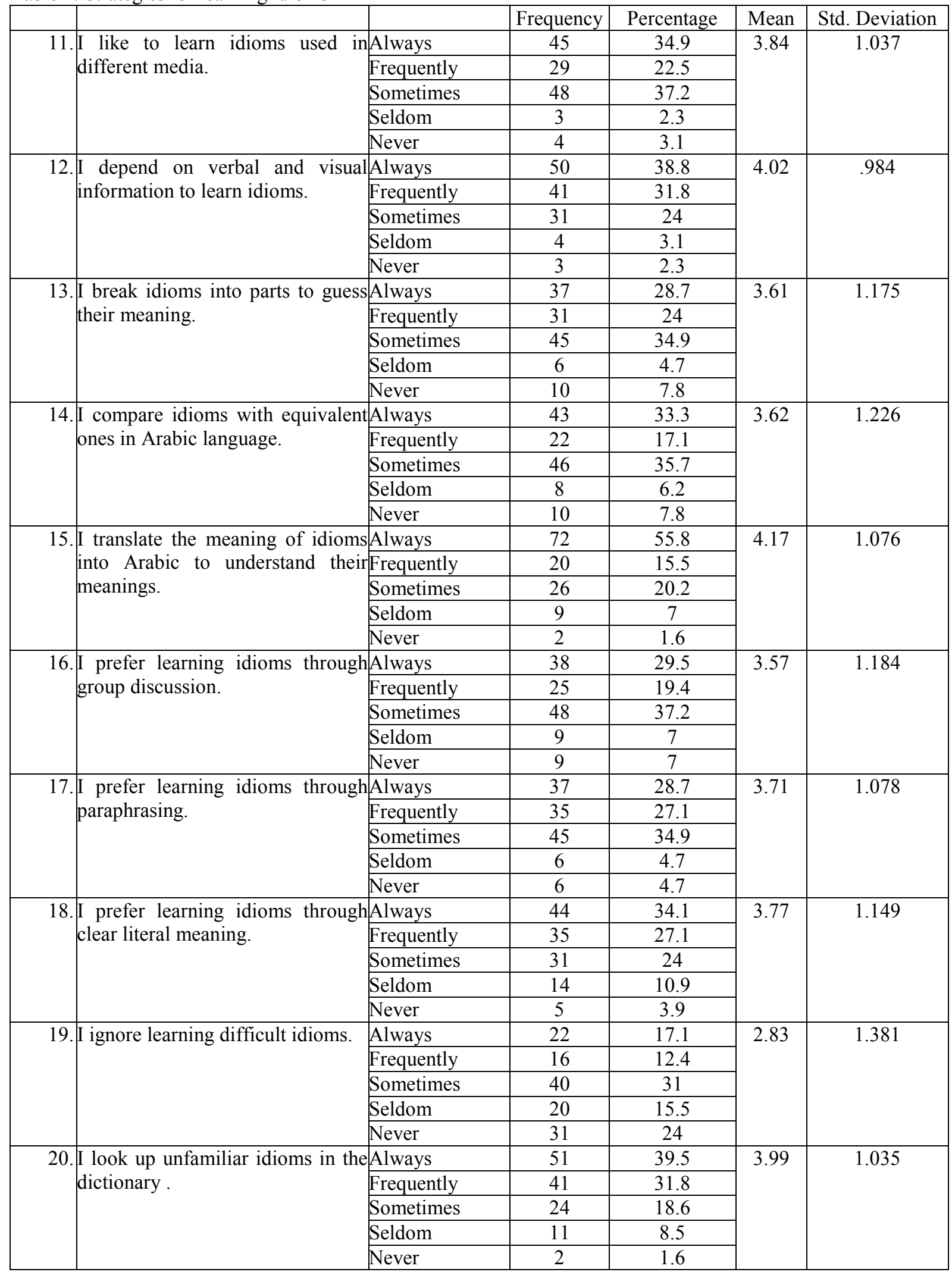




\begin{tabular}{|c|c|c|c|c|c|c|}
\hline & & & Frequency & Percentage & Mean & Std. Deviation \\
\hline 21. & I learn idiomatic expressions & Always & 46 & 35.7 & \multirow[t]{5}{*}{3.71} & \multirow[t]{5}{*}{1.182} \\
\hline \multirow{4}{*}{\multicolumn{2}{|c|}{ through putting them in sentences. }} & Frequently & 23 & 17.8 & & \\
\hline & & Sometimes & 42 & 32.6 & & \\
\hline & & Seldom & 12 & 9.3 & & \\
\hline & & Never & 6 & 4.7 & & \\
\hline \multirow[t]{5}{*}{22.} & I guess the meaning of idiomatic & Always & 60 & 46.5 & \multirow[t]{5}{*}{4.04} & \multirow[t]{5}{*}{1.107} \\
\hline & \multirow[t]{4}{*}{ expressions from the context. } & Frequently & 30 & 23.3 & & \\
\hline & & Sometimes & 28 & 21.7 & & \\
\hline & & Seldom & 6 & 4.7 & & \\
\hline & & Never & 5 & 3.9 & & \\
\hline & I learn idioms outside the & Always & 24 & 18.6 & \multirow[t]{5}{*}{3.17} & \multirow[t]{5}{*}{1.251} \\
\hline & \multirow[t]{4}{*}{ classroom. } & Frequently & 24 & 18.6 & & \\
\hline & & Sometimes & 28 & 37.2 & & \\
\hline & & Seldom & 16 & 12.4 & & \\
\hline & & Never & 17 & 13.2 & & \\
\hline \multirow[t]{5}{*}{24.} & \multirow[t]{5}{*}{ I predict the meaning of idioms. } & Always & 75 & 58.1 & \multirow[t]{5}{*}{4.31} & \multirow[t]{5}{*}{.975} \\
\hline & & Frequently & 28 & 21.7 & & \\
\hline & & Sometimes & 20 & 15.5 & & \\
\hline & & Seldom & 3 & 2.3 & & \\
\hline & & Never & 3 & 2.3 & & \\
\hline & I learn idioms better through & Always & 48 & 37.2 & \multirow[t]{5}{*}{4.02} & \multirow[t]{5}{*}{.948} \\
\hline & \multirow[t]{4}{*}{ memorization. } & Frequently & 44 & 34.1 & & \\
\hline & & Sometimes & 32 & 24.8 & & \\
\hline & & Seldom & 2 & 1.6 & & \\
\hline & & Never & 3 & 2.3 & & \\
\hline \multirow{5}{*}{\multicolumn{2}{|c|}{$\begin{array}{l}\text { 26. I learn English idioms better in the } \\
\text { classroom. }\end{array}$}} & Always & 45 & 34.9 & \multirow[t]{5}{*}{3.81} & \multirow[t]{5}{*}{1.105} \\
\hline & & Frequently & 33 & 25.6 & & \\
\hline & & Sometimes & 36 & 27.9 & & \\
\hline & & Seldom & 11 & 8.5 & & \\
\hline & & Never & 4 & 3.1 & & \\
\hline
\end{tabular}

As shown in the Table 2 , The participants used several strategies for learning idioms. The highest mean score was 4.31 and the lowest was 2.83 . It is clear cut that the majority of the participants depended on predicting the meaning of the idioms $(\mathrm{m}=4.31)$. This means that students use this strategy because they think that it may help them a lot and make the process of learning idioms easy and simple. The second most frequently used strategy according to the students' opinions was translating idioms' meaning into Arabic $(\mathrm{M}=4.17)$. The participants believed that the most understandable idioms were those that have an equivalent meaning in the Arabic language. Students may understand the meaning of English idioms easily if there is a similarity between both the Arabic language and the English languages. Using translating strategy to know the meaning of idioms shows that the learners rely heavily on their first language to understand idiomatic expressions because they do not have good knowledge of English vocabulary. Saleh \& Zakaria (2013) and Alhaysony (2017) assert what this result ends up.

Guessing the meaning of English idioms from the context was the third strategy that students applied in their learning $(M=4.04)$. This confirms that context plays an important role in learning idiomatic expressions. Qualls, O'Brien, Blood and Hammer (2003) found that contextual cues are imperative for understanding new idioms in written and spoken contexts. This results goes with other researchers' findings about the significance of context in the process of learning idioms (Irujo, 1986; Rohani et al., 2012; Saleh \& Zakaria, 2013).

The next most frequently used strategy according to the participants' responses was depending on verbal and visual information to learn idioms and learning idioms through memorization $(\mathrm{m}=4.02)$. This means that they expand their knowledge of English idioms through applying this strategy. Students should use verbal and visual information to understand new idioms. In fact, such figurative expressions are learned in interactive conditions, and media language generally contains idioms along with contextual clues that help students memorize the meaning of such expressions (Al-Khawaldeh et al., 2016; Irujo, 1986).

Looking up unfamiliar idioms in the dictionary was the next strategy applied by the students $(M=3.99)$. They try to identify the meaning of idioms through going to look up the meaning of unfamiliar words in the dictionary. Moreover, EFL students utilized other strategies during their learning idioms. These strategies include learning idioms used in different media $(\mathrm{m}=3.84)$, learning English idioms better in the classroom $(\mathrm{M}=3.81)$, learning idioms through clear literal meaning $(\mathrm{M}=3.77)$, learning idioms through paraphrasing 
$(M=3.71)$, learning idioms by using them in sentences $(M=3.71)$, comparing idioms with equivalent ones in Arabic language(3.62), and breaking idioms into parts to guess their meaning( $M=3.61)$. This result corresponds with the researchers' findings about the importance of including context in the process of learning idioms (Alhaysony ,2017; Irujo, 1986; Rohani et al., 2012; Saleh \& Zakaria, 2013).

The participants did not commonly use the remaining strategies, including group discussion(3.57), communicating outside the classroom (3.17), and ignoring difficult idioms (2.83). These findings are consistent with those of Alhaysony (2017) and Al-Khawaldeh et al. (2016).

\section{Conclusion and Pedagogical Implications}

This study investigated the difficulties that learners face when learning idiomatic expressions as well as the strategies that they use to understand such expressions. The findings of the study revealed that the participants faced several difficulties when learning idioms. These difficulties forced instructors to use different educational techniques and strategies to help students overcome such difficulties. Besides, students should develop their language skills through idiom-based learning. The results revealed different reasons behind the difficulty of learning idioms. For example, lacking foreign cultural background, presenting idioms in a manner that mirrors real-life language use, understanding English figurative expressions, using idioms in oral communication, and practicing idioms in different communicative contexts. Based on these findings, curriculum designers as well as teachers should pay more attention to the process of teaching and learning idioms and include them in English textbooks.

The results also illustrated the most frequently used strategies among EFL students. For example, predicting the meaning of idioms, translating them to the first language, guessing the meaning of idiomatic expressions from the context, depending on verbal and visual information, and looking up unfamiliar idioms in the dictionary. This indicates that the students use several strategies to improve their learning and overcome different difficulties. Finally, it would be very interesting to conduct further studies on this issue using more participants from different nationalities and different places.

\section{References}

Abu-Afeefa, R. (1987). Transfer in the Acquisition of English Idioms by Jordanian University Students. Unpublished M.A Thesis. Yarmouk University, Irbid, Jordan

Al-Hassan, H. (2007). In Guessing the Meaning of Idioms: Efficiency and Techniques. Unpublished M.A Thesis, University of Bahrain. Retrieved on 15th July, 2021 from http://search.proquest.com. ezlibrary.ju.edu.jo/docview /304773490?accountid=27719

Alhaysony, M. H. (2017). Strategies and Difficulties of Understanding English Idioms: A case study of Saudi University EFL Students. International Journal of English Linguistics, 7(3), 70-84.

Al-Khawaldeh, N., Jaradat, A., Al-momani, H., \& Bani- Khair, B. (2016). Figurative Idiomatic Language: Strategies and Difficulties of Understanding English Idioms. International Journal of Applied Linguistics and English Literature, 5(6), 119-133.

Alexander, R. (1987). Problems in Understanding and Teaching Idiomaticity in English. Anglistik and Eneglichunterricht, 32(2), 105-122.

Asri,A. and Rochmawati, D. (2017) .Innovative Teaching Of English Idiomatic Expressions For EFL Learners. Journal of English Teaching Adi Buana, 2 (1),47-58.

Baker, M. (1992). In Other Words: A Course Book on Translation. London: Routledge. https://doi.org/10.4324/9780203327579.

Beloussova, V. (2015) .Idiom Learning Materials for Estonian Secondary School Students. Unpublished MA thesis. University of Tartu.

Brenner, G. (2011). Webster's New World American Idioms Handbook. New York: Houghton Mifflin Harcourt.

Burke, D. (1998). Without Slang and Idioms, Students Are In the Dark! ESL Magazine, 1(5), 20-23.

Charteris-black, J. (2002). "Second Language Figurative Proficiency: a Comparative Study of Malay and English." Applied Linguistics, 23(1), 104-133.

Chen, Y. and Lai, H. (2013). Teaching English Idioms as Metaphors through Cognitive-Oriented Methods: A Case in an EFL Writing Class. English Language Teaching, 6(6), 13-20.

Cooper, T. C. (1999). "Processing of Idioms by L2 Learners of English." TESOL Quarterly. Vol. 33 (2), 233 262.

Crystal, D. (1991). A dictionary of Linguistics and Phonetics. 3rd ed. Oxford. Blackwell press.

De Caro, E. E. R. (2009). The Advantages and Importance of Learning and Using Idioms in English. Cuademos de Linguistica Hispanica, 14, 121-136.

Glucksberg, S. (1993). Idiom Meaning and Allusional Content. Cognitive Linguistics. 8(3):183-206.

Irujo, S. (1984). The Effect of Transfer on the Acquisition of Idioms in a Second Language. Unpublished Doctoral Dissertation. Boston University. Retrieved on 12th July, 2021 from http://search. 
proquest.com.ezlibrary.ju.edu.jo/docview/303325315?accountid=27719

Lennon, P. (1998). Approaches to the Teaching of Idiomatic Language. IRAL, 36(1) ,1-11.

Mäntylä, K. (2004) . Idioms and Language Users: The Effect of the Characteristics of Idioms on Their Recognition and Interpretation by Native and Non-Native Speakers of English. Unpublished PhD thesis, Jyväskylä University.

My,V. and Loi,N.(2020) An Investigation Of Vietnamese EFL Teenage Learners' Knowledge Of Common English Idioms: Implications For Idiom Instruction. European Journal of Foreign Language Teaching, 5(1), 48-67.

O‘Malley, J. M. and A. U. Chamot (1990). Learning Strategies in Second Language Acquisition. Cambridge: Cambridge University Press.

Orfan, S. (2020). Afghan EFL Students' Difficulties and Strategies in Learning and Understanding English Idioms. Cogent Arts and Humanities, 7(1), 1-13.

Qualls, C., O’Brien, R., Blood, G., \& Hammer, C. (2003). Contextual Variation, Familiarity, Academic Literacy, and Rural Adolescents' Idiom Knowledge. Language, Speech and Hearing Services in School, 34, 69-79.

Rohani, G., Ketabi S. and Tavakol. M (2012). The Effect of Context on the EFL Learners' Idiom Processing Strategies. English Language Teaching, 5( 9),104-114.

Saleh, N., \& Zakaria, N. (2013). Investigating the Difficulties Faced in Understanding, and Strategies Used in Processing English Idiom by the Libyan students. International Journal of English Language and Translation Studies, 1(2), 69-90.

Strakšiene, M. (2009). Analysis of Idiom Translation Strategies from English into Lithuanian. Studies about Language, 13-20.

Yunus, K. and Hmaidan, M (2021).The Strategies Used By Lecturers In Teaching Translation Of Idiomatic Expressions. International Journal of Education, Psychology and Counseling, 6(40), 134-144.

Zarei, A. (2020). L2 Idioms: On the Effectiveness of Teaching Techniques. Teaching English Language, 14(2), 217-238.

Richards, J., \& Schmidt, R. (1990). Longman Dictionary of Language Teaching and Applied Linguistics. London:Longman.

SelvaRaj, S. and Hua, T. (2019). Rural ESL Teachers' Acumen in Teaching Idioms: Traditional and Modern Methodology. International Journal of Innovative Technology and Exploring Engineering, 9(2), 2594-2601.

Ta'amneh, M. (2014). Investigating Vocabulary Learning Strategies used by Pre-Service Teachers at Taibah University in learning English Vocabulary Items. International Interdisciplinary Journal of Education, 3 (3), 143-148.

Ta'amneh, M. (2015). Exploring the Harmony between Jordanian EFL Teachers' and Students' Beliefs about Vocabulary Learning Strategies. Journal of Language Teaching and Research (JLTR), 6 (1),78-84.

Zyzik, E. (2011). Second Language Idiom Learning: The Effects of Lexical Knowledge and Pedagogical Sequencing. Language Teaching Research, 15(4), 413-433. 